\title{
Maintaining a Balance of Private and Public Interests in Agricultural Land Transactions Within the Digital Economy Development
}

\author{
Lesnykh A.V. \\ Oryol State University named after I.S. Turgenev, 302001, Oryol, Russia \\ Email: lesnyh1@mail.ru
}

\begin{abstract}
Up to the present, land resources in general and agricultural land, in particular, form the basis of human life activity, acting either as a means of food production or at least a spatial basis for economic activity in principle. It is important to take into account that the guarantee of these activities' effectiveness is the land market development, a regulated system of land transactions. Inversely, the effectiveness of such transactions is impossible without transparency, the openness of information about land plots as the basis of land and legal transactions. In the modern context of digital economy formation and development, such openness is achieved through the introduction and development of electronic land accounting systems, which integrates the land market into the information space. However, it should be remembered about the need to maintain a balance of private and public interests in the course of using these technologies. The article is devoted to the named problems.
\end{abstract}

Keywords: balance of interest, openness, transactions, land plot, digitalization, information system, public

cadastral map

\section{INTRODUCTION}

According to para.1 Art. 80 of the Land Code of the Russian Federation a land redistribution fund is being formed in order to redistribute land for agricultural production, for peasant (farm) holdings activities, to expand such activities, to create and expand smallholdings, for horticulture, animal husbandry, vegeculture, haymaking, cattle grazing as part of agricultural land. While para. 4 of the aforementioned article assumes information about these land resources as public knowledge. In other words, recognizing the indisputable importance of the land redistribution fund in economic activity, the legislator calls the transparency of these lands characteristics as a significant factor in such activity effectiveness. Moreover, the openness of information about a particular property unit, including land, is recognized by the Russian state as a fundamental necessity of the domestic land market.

In accordance with clause 11 para. 1 art. 1 of the Land Code of the Russian Federation, Russian land legislation is based, inter alia, on the principle of combining the interests of society and the legitimate interests of citizens, according to which the regulation of the land use and protection is performed for the benefit of the whole society while providing guarantees for each citizen for free ownership, use and disposal of his land. As S.A. Bogolyubov notes, this principle, in the course of legal regulation of land relations, consists in the necessity of such a balance of private and public interests, which should be a foundation stone of all legal regulation, that is, be basic for other branches of law. This is a key task for both the government and its legal norms. Of course, the specifics of certain social relations should be taken into account, while understanding that the degree to which both private and public interests will be taken into account will vary depending on the legal relationship content. Relating to land law, the problem of finding the optimal combination of these interests is manifested in a number of relations coming from the economic use of land resources (for example, when taking plots of agricultural land for state or municipal needs, during the land privatization, when establishing, such as a public easement or land provision for construction and changing their categories if necessary) [14].

In modern Russia, with the market relations formation and development, the need to establish and maintain a balance between public and private interests is recognized as an important condition for legal regulation 
of public relations. It should be emphasized that the requirement to maintain a balance of public and private rights is a leading principle developed by the European legal model and applied in resolving property disputes within property rights protection.

The consistent implementation of the principle of private and public interests balance is the key beginning of the legal regulation of land transactions as property units (including land plots from agricultural land. It should be noted that according to clause 1 para. 1 Art. 1 of the Land Code of the Russian Federation, the legal regulation of legal relations coming from land use and protection performs based on a three-way understanding of the "land" category by the domestic legislator: as a natural object, a key component of the environment; as a land resource, the main means of production in agriculture and forestry; as well as the spatial basis of economic activity throughout the entire territory of Russia. At the same time, one should not ignore the regulatory understanding of land as the substantive part of a land plot, that is, a property unit that is a key element of civil law transactions in the agricultural sector. The legal literature rightly states that these requirements of the Land Code constitute the basis of the regulatory impact on legal relations in the land sector [17].

\section{MATERIALS AND METHODOLOGY}

By the information letter dated December 20, 1999 [9], the Presidium of the Supreme Arbitration Court of the Russian Federation noted that the requirement to maintain a balance of public and private interest in resolving a property dispute means that the European Court of Human Rights when deciding on the protection of property rights, assesses how balanced the act of the national court allows to solve the issue of protecting the rights of a private person, observing the interests of society. The principle of private and public interests balance is applied by the European Court to the protection of property rights of both individuals and legal entities.

In economic activity, private and public interests interact very closely relating to agricultural lands. On the one hand, private interest necessitates to intensify the use of land resources to obtain the maximum economic effect and increase agricultural productivity, which in turn has a beneficial effect on national food security. On the other hand, such overexploitation of land resources inevitably has a negative impact on these resources, and after that - a direct negative impact on the whole state of the environment, and therefore the health of the population. And this contradiction can be resolved only by the consistent implementation of the principle of maintaining a balance of private and public interests in land use with the establishment (which was repeatedly noted in the scientific literature [12]) of business entities responsibility for observing the fixed procedure for land use and the requirements for replenishing resources lost during production activities. These circumstances acquire a special significance in a decrease in the number of the rural population, which has been repeatedly highlighted in the scientific literature [20].

It should be noted that para. 7 of the Food Security Doctrine of the Russian Federation, approved by Decree of the President of the Russian Federation No. 20 dated January 21, 2020, states sustainable development of domestic production of food and raw materials sufficient to ensure food independence of the country as one of the main tasks of ensuring food security, regardless of changes in external and internal conditions. Moreover, the noted sustainable agricultural production is impossible without the equally stable functioning of the legal regulation system of economic activity and, above all, the production base of such production, i.e., land.

\section{RESULTS AND DISCUSSION}

The Fundamentals of state policy of use of the land fund of the Russian Federation for 2012-2020 approved by Decree of the Russian Federation Government No. 297-r dated March 3, 2012, state providing conditions for increasing the civil land transactions efficiency as one of the main tasks of the state policy for managing the land fund. At the same time, it is noted that the main directions of the state policy of land fund management for solving the noted problem should include measures to improve land management and develop state monitoring of lands, which in turn involves the development of state monitoring of lands, information support for state land control over the use and protection of lands, other functions in state and municipal land management, as well as providing citizens, legal entities, government authorities and local authorities with information on the land state. The latter fact is essential for the urban agglomerations expansion, which is what domestic science draws attention to [19].

The land transactions publicity as one of its key principles goes back to Roman law. In fact, the constitutions of the emperor Leo, the norms of which created actus publicus [10], the presence of which meant the openness of information about land resources can be quite possible recognized as the first attempts to make land relations public. On the other hand, even before that, imperial Egypt had an institute of land books, which, however, did not receive a general Roman distribution. Thus, at the dawn of its formation, the Roman state sees its land resources as its exceptional feature and significance for state building. On this basis, the economic use of agricultural land without state 
participation is impossible at no cost in statehood. The forms and degree of such participation determine not only the economic but also the political development of the state.

It is not an overstatement to recognize the institution of local books developed in medieval Europe during the circulation of feudal estates as a direct consequence of the impact of Roman law. In the literature, it is noted that they essentially became the starting points of today's land registration. In Austria, these are Bohemian local books, in France - coutumes de nantissement, in Germany - patrimonial books of Hamburg city, Bremen city and some imperial cities, etc. [13].

In modern times, European property law formulated a key feature of immovable property existence: the publicity of its ownership and statutory state control over its transaction and use. The land ownership publicity institution is complex in its established nature and is a combination of three elements:

1) the need for state registration of a land plot (property) as a geographical object, with fixing its borders on the ground to ensure the possibility of its topographic identification;

2) the need for state registration of rights to a land plot to ensure guarantees of the titleholder rights;

3 ) the need to register encumbrances and restrictions on land rights, if any.

Today, the land transactions publicity is ensured by a special state registration system - the land cadastre, the existence of which is generally subordinated to the essence of the above-mentioned elements of publicity. On the one hand, cadastre acts as a means of guaranteeing the rights of land owners, and on the other hand, as a means of territorial planning and management, including taxation [15].

As of today, the scientific literature distinguishes four types of cadastral systems. Among them:

French (Napoleonic), typical for the countries of Roman Europe, the key principle of creation of which was the development of a land taxation base, while registries of immovable property contain information about real rights to the land plots of holders, information about the transfer of rights, the grounds for transfer and the rights of third parties;

German (countries of central and eastern Europe, including Russia), which is an interacting combination of a land book and a land cadastre, while the cadastre contains geographical and semantic information about the land (including information about the buildings available on it), and the land book serves as a means of establishing and fixing the rights to these plots, while it is worth saying that now there is a tendency to combine the land cadastre and land book into a single information system (this takes place in present-day Germany);
English (Great Britain and a number of Englishspeaking countries), which is a parallel accounting of land (topographic, fiscal and registration of holders),

Scandinavian (Northern Europe and the Baltic countries), for which a common feature is the formation of a single, multi-purpose cadastre, representing a synthesis of large-scale topographic maps and a state register of land titles.

Herewith, the common European trend is the transformation of land cadastre materials into electronic form and the placement of its materials in the public domain. So the official information cadastral system in Germany is ALKIS (Amtliches LiegenschaftskatasterInformationssystem), which is one of the three elements of the AFIS $\AA$-ALKIS $₫$-ATKIS $®$ concept, a universal, integrated land accounting system. It was introduced on July 29,2010 , and is intended to ensure the operability of the German cadastral system. The named software product is digitized documentation of the cartographic material of the real estate cadastre (ALK - Real Estate Map) and the Property Book (ALB) [21].

In France, in 1990, the Minister of Finance, in charge of the cadastre, decided to create a Digital Cadastral Plan (GPI), but there is no single centralized cadastral system yet. Her Majesty's Land Register has been established and is operating in the UK. Since December 1990, the register has been public, before that only real estate owners had access to information. Since 2000, access to the register of immovable property is possible online.

In the present context of a post-industrial society, the importance of information is increasing many times. Moreover: information turns into a strategic resource, the key to the successful social and economic development of the state, effective business and fullfledged personality development. It can be safely said that information has become one of the leading factors in public life, an external form of publicity, a way of influencing on, among other things, emerging legal relations, and the information function of land registers is increasingly taking the leading place [16]. It is not surprising that, back in 1994, the European Union has called the knowledge society development as a priority. In the "Recommendation to the European Council: Europe and the global information society" ("Bangemann report") [11] economic and social development is directly linked to the information technology development, improvement of technical communication tools. Specific response plan of the European Union was developed in the same year and was called the "European Path to the Information Society". Russia is not an exception in this regard. Moreover: according to the "Property Registration" indicator in the Doing Business-2017 rating, we can safely say that the Russian Federation is among the world leaders in the efficiency of the accounting and registration system. According to this indicator in 2017 
the Russian Federation took 9th place. For comparison: The United States took 36th place in this ranking, Germany - 79th, the United Kingdom - 47th, France 100th, and China - 61st [18].

In Russia, public cadastral maps began to be introduced in 2010 based on requirements of the Federal Law N 221-FZ "On Cadastral Activities" dated July 24, 2007 (of that time version of the Federal Law "On the State Real Estate Cadastre"). According to para. 4 of Art. 13 of the Federal Law N 221-FZ "On Cadastral Activities" dated July 24, 2007, the cadastral registration authority maintains cadastral maps intended for use by an unrestricted group of people — public cadastral maps. Public cadastral maps are to be posted on the official website of the cadastral registration authority on the Internet. Scope of public cadastral maps information was determined by the Order of the Ministry of Economic Development of the Russian Federation $\mathrm{N}$ 416 "About establishment of the list of types and the scope of information of cadastral maps" dated October 19, 2009

For information, on March 1, 2010, the Public Services Online Portal (PSOP or Portal), provided by Rosreestr in electronic form, was entered into trial operation, which included the first version of the Web application of the Public Cadastral Map (PCM or Appendix). The Rosreestr Public Services Online Portal is available at https://portal.rosreestr.ru. Access to the electronic public cadastral map of Rosreestr is performed either from the "Services" section of the Portal or via the link http://maps.rosreestr.ru/Portal.

Currently, according to para. 1 of Art. 12 of the Federal Law N 218-FZ "On State Registration of Real Estate" dated July 13, 2015, cadastral maps are cartographicbased thematic maps on which the information contained in the Unified State Register of Immovable Property is reproduced in graphical and textual form and is divided into public, intended for unlimited access by all interested parties, and on-duty, held for official use by the executive body of special competence in real estate accounting - the Federal Service for State Registration, Cadastre, and Cartography.

The law directly indicates the integration of the public cadastral map with the Unified State Register of Immovable Property, which allows this resource to be a comprehensive information base not only on the boundaries of property units but also on property rights to these units. Scope of information contained in the cadastral maps is determined by the Order of the Ministry of Economic Development of the Russian Federation N 145 "On approval of the scope of the information contained in the cadastral maps" dated March 17, 2016, and with respect to land plots includes a cartographic designation of the land plot boundaries, cadastral registration number, land plot area, its actual address, category and permitted use, information on ownership form, the cadastral value used for tax purposes.

Public cadastral maps are to be posted on the official website for viewing without submitting requests or charging.

\section{CONCLUSIONS}

Information support for agricultural land use is aimed at creating a single information space; providing information support for the agricultural land use; developing a base for taxation; support for investment projects; developing a base for geographic information systems

Development of a comprehensive information base on the land state and its dynamics will contribute to improving the efficiency of agricultural land use. The main component of information support for land use is cadastral information, which officially confirms the quantitative and qualitative characteristics of land plots, as well as their value [23].

The Fundamentals of the state policy of use of the land fund of the Russian Federation for 2012-2020 approved by Decree of the Russian Federation Government $\mathrm{N}$ 297-r dated March 3, 2012, among the main tasks of the state policy on managing the land fund, establish the need to ensure conditions for improving the efficiency of civil transactions of land, including aimed at protecting rights to immovable property, as well as to reduce administrative barriers and ensure taxation of property. At the same time, the general availability of information about the characteristics of a land plot as a property unit appears as an effective way to increase the stability of civil law transactions of land property.

\section{REFERENCES}

[1] Konstitutsiya Rossiyskoy Federatsii. Prinyata 12.12.1993 g. // Rossiyskaya gazeta. - 25 dekabrya 1993 g. - N 237; Sobraniye zakonodatel'stva RF. 2014. No. 31.St.4398.

[2] Zemel'nyy kodeks Rossiyskoy Federatsii ot 25 oktyabrya 2001 g. No. 136-FZ // Sobraniye zakonodatel'stva RF. - 2001. - No. 44. - St. 4147; 2015. - No. 30. - St. 3735.

[3] Federal'nyy zakon ot 13.07.2015 No. 218-FZ (red. ot 02.08.2019) "O gosudarstvennoy registratsii nedvizhimosti" (s izm. i dop., vstup. v silu s 
[13] I.A. Bazanov, Proiskhozhdeniye sovremennoy ipoteki. - M.: tipografiya Levekson, 1900. - 592 s.

[14] S.A. Bogolyubov, Kommentariy k Zemel'nomu kodeksu Rossiyskoy Federatsii.- M.: Prospekt, 2014. - 648 s.

[15] A.A. Varlamov, Zarubezhnyye zemel'no kadastrovyye sistemy // Imushchestvennyye otnosheniya. - 2007. - No. 7 (10). - S. 60-68

[16] A. Vudarskiy, Otkrytyy kharakter zemel'nykh registrov: sravnitel'no-pravovoy analiz $\mathrm{v}$ yevropeyskom kontekste // Vestnik SPbGU. Ser. 14. Pravo. - 2016. Vyp. 4. - S. 58 - 81

[17] Ye.A. Galinovskaya, Osobennosti vklyucheniya zemli $\mathrm{V}$ pravovyye otnosheniya $\mathrm{v}$ kachestve ob"yekta // Zhurnal rossiyskogo prava. 2012.- No. 8. - S. 105-111

[18] Doklad Vsemirnogo banka i Mezhdunarodnoy finansovoy korporatsii "Vedeniye biznesa v 2017 godu" // Rezhim dostupa: https://gtmarket.ru/news/2016/10/26/7312

[19] Ye.K. Kuricheva, Zhilishchnoye stroitel'stvo v Moskovskoy aglomeratsii: prostranstvennyye posledstviya // Vestnik MGU. Seriya 5. Geografiya. 2017. - No. 3. - S. 87 - 91

[20] T.G. Nefedova, N.V. Mkrtchyan, Migratsiya sel'skogo naseleniya i dinamika sel'skokhozyaystvennoy zanyatosti v regionakh Rossii // Vestnik MGU. Seriya 5. Geografiya. - 2017. No. 5. - S. 58-68.

[21] Territorial'nyy organ gosudarstvennogo prava. Available at: http://www.bochum.de/, svobodnyy. Zagl. s ekrana. - YAz. nem.

[22] A.A. Rasskazova, Ekonomicheskaya effektivnost' sel'skokhozyaystvennogo zemlepol'zovaniya $\mathrm{v}$ regione (na materialakh Moskovskoy oblasti): avtoref.dis..kand. ekonom. nauk M., 2006. - 31 s.

[23] I.A. Khabarova, D.A. Khabarov, T.R. Altynbayev, A.A. Blyablin, S.YU. Rodovnichenko, Informatsionnoye obespecheniye effektivnogo sel'skokhozyaystvennogo zemlepol'zovaniya // Mezhdunarodnyy zhurnal prikladnykh nauk i tekhnologiy "Integral". - 2018. - No. 2. - S. 2-13. 